\title{
Entre a liberdade e a ordem: 0 jornal 0 Estado de São Paulo e a ditadura (1969-1973)
} Between liberty and order: 0 Estado de São Paulo and the dictatorship (1969-1973)
Entre la libertad y el orden: el periódico 0 Estado de São Paulo y la dictadura (1969-1973)

Rodrigo Patto Sá Motta*

\begin{abstract}
Resumo: O artigo analisa as representações políticas divulgadas pelo jornal Estadão no período mais agudo da ditadura, a fase entre o AI5 e o começo da distensão do governo Geisel. O objetivo é compreender as estratégias do jornal diante da ditadura militar que, de acordo com a análise apresentada neste texto, variaram entre a adesão e a acomodação. No período em foco, o Estadão batalhou para trazer a ditadura mais perto dos valores liberais e para isso lançou mão tanto de recursos verbais como visuais, assumindo riscos que acabariam provocando a censura prévia. A parte final do artigo aborda a estratégia do jornal no debate sucessório do governo Médici, quando pressionou para que o novo presidente iniciasse um processo de institucionalização ou normalização, o que nos termos do periódico significava fortalecer as instituições liberais sem romper com o poder militar.
\end{abstract}

Palavras-chave: Imprensa; Ditadura; Caricatura; Censura; Acomodação.

Abstract: The article analyses the political opinions published by the newspaper $O$ Estado de São Paulo during the phase between the AI5 and Geisel's distension, which was the harsher period of the Brazilian dictatorship. The aim is to understand the periodical's strategies towards the dictatorship, which varied between adhesion and accommodation according to the analysis presented here. During the period on focus, Estadão worked to bring the dictatorship closer to liberal positions and, for that purpose, the newspaper used both verbal and visual resources. Following this path the newspaper assumed risks that, in the end, provoked the state censorship. The article's last section approaches Estadão's strategies during the debates concerning Médici's succession, when the newspaper made pressure on behalf of a process of normalization or institutionalization, which meant for Estadão strengthening the liberal institutions without breaking with the militaries.

Keywords: Press; Dictatorship; Caricature; Censorship; Accommodation.

Resumen: El artículo analiza las representaciones políticas publicadas por el diario O Estado de São Paulo durante el periodo entre el AI5 y la distensión de Geisel, que fue la etapa más dura de la dictadura brasileña. El objectivo es comprender las estrategias del diario hacia la dictadura, que van desde la adhesión hasta la acomodación. Durante el período en analisis, el Estadão trabajó para traer la ditadura más cerca de los valores liberales y para ello utilizó recursos verbales y visuales. Siguiendo ese caminho el diario tomó riesgos que eventualmente provocaron la censura previa estatal. En la parte final del artículo se analiza las estratégias del diario durante los debates de la sucesión de Médici, cuando Estadão presionó a favor de un proceso de normalización o institucionalización de la dictadura, lo que significaba para el diario fortalecer las instituciones liberales sin romper con el poder militar.

Palabras clave: Prensa; Dictadura; Caricatura; Censura; Acomodación.

\footnotetext{
* Professor do Departamento de História da Universidade Federal de Minas Gerais (UFMG) e pesquisador do CNPq.
} dados biográficos_biographic data 
O texto é resultado de pesquisa ${ }^{1}$ que analisa os principais veículos da mídia carioca e paulista (Jornal do Brasil, O Globo, Correio da Manhã, Última Hora, O Estado de São Paulo, Folha de São Paulo) durante a ditadura, com o objetivo de compreender as relações entre a grande imprensa e o regime autoritário. Diante da impossibilidade de estudar toda a mídia nacional a escolha foi enfatizar os jornais dos estados do Rio de Janeiro e de São Paulo, com base no entendimento que eles têm maior circulação e impactam a imprensa de outras regiões, embora não resumam a complexidade do país.

Trata-se de uma abordagem política, portanto, e que encara os jornais simultaneamente como objeto e fonte. O interesse é compreender as posições políticas assumidas por esses veículos da imprensa diante do Estado autoritário, como eles se relacionaram com a ditadura que, significativamente, a maioria chamava de revolução. Para analisar o comportamento desses periódicos em face da ditadura - mais precisamente, as representações que eles divulgaram sobre o Estado de exceção - a opção é considerar uma escala de atitudes variando entre adesão, acomodação e resistência, partindo do suposto que elas mudaram com o tempo e se combinaram, às vezes, no mesmo jornal.

Algumas breves observações metodológicas se fazem necessárias. Neste estudo são considerados tanto os discursos verbais como os visuais, especificamente, as representações divulgadas por meio de editoriais, textos de opinião, reportagens, charges e caricaturas. Há que estar atento às especificidades das diferentes formas de representação: há charges que apenas figuram argumentos do discurso verbal, enquanto outras inauguram novos temas e formas de expressão política. De qualquer modo, no artigo serão privilegiados os discursos verbais, embora algumas charges mais expressivas sejam abordadas também.

Neste texto a análise se restringirá ao diário Estado de São Paulo, popularmente conhecido por Estadão. A ideia inicial era tratar simultaneamente todos os periódicos pesquisados, mas o formato do artigo tornou difícil a empreitada, de maneira que uma comparação mais ampla será realizada em outro momento. Essa opção será melhor compreendida no decorrer da leitura, na medida em que se revelar a complexidade

\footnotetext{
1 A pesquisa tem apoio do CNPq (Bolsa de produtividade) e da Fapemig (Programa Pesquisador Mineiro). Uma versão inicial deste texto foi apresentada no Seminário Quem quer jornais de ontem?, realizado na Casa de Rui Barbosa em setembro de 2016 sob a coordenação de Isabel Lustosa e Tania de Luca.
}

das posições do periódico e sua importância no cenário político e midiático.

Igualmente devido aos limites do artigo seria impossível abordar as atitudes e discursos políticos do Estadão durante toda a ditadura. Por isso a decisão de enfocar um período curto, mas fundamental, cuja importância contrasta com a pouca atenção recebida dos pesquisadores. Trata-se da fase entre a edição do $\operatorname{AI5}(13 / 12 / 1968)$ e a ascensão de Ernesto Geisel, o quarto presidente militar, no início de 1974. Esse período é importante devido a vários fatores, alguns bastante conhecidos, como a intensificação da censura e o agravamento da repressão política, e também pelo surto de crescimento econômico originador da imagem do "milagre", que ajudou a transformar Emílio Médici, o militar então no comando, no presidente mais popular da ditadura. Mas os anos 1969-1973 importam, também, porque nesse período a ditadura distanciou-se mais dos valores liberais (tanto em sentido político como econômico), deixando as instituições políticas, notadamente o poder legislativo e os partidos, em virtual estado de coma, ao mesmo tempo em que líderes de direita encastelados no poder tentaram formular um projeto ideológico não liberal para a "revolução".

Esse conjunto de elementos representou grande desafio para os atores envolvidos no cenário da época, notadamente a imprensa, que enfrentou um dilema diante da ditadura: como conciliar a manutenção da ordem social com a devoção à liberdade, especialmente a sua liberdade? (MOTTA, 2013) Os principais veículos da mídia partilhavam (partilham ainda) as convicções antiesquerdistas e anticomunistas comuns aos setores sociais dominantes, por isso apoiaram com entusiasmo a intervenção militar, mais do que isso, ajudaram a provocá-la. No entanto, não desejavam uma ditadura que tolhesse sua liberdade de expressão, ou seja, a censura era admissível apenas para impressos de menor porte ou de esquerda. Alguns veículos da grande mídia tampouco desejavam que a ditadura ameaçasse a perspectiva liberal em outros pontos também, como o predomínio do mercado e das empresas privadas.

É verdade que nem todos os veículos da imprensa podem ser descritos segundo as linhas acima, pois alguns eram balcões de negócios comandados por quem pagava mais. Porém, as empresas mais tradicionais tinham de fato compromissos com a liberdade, tal como a entendiam, evidentemente. Em outras palavras, a grande mídia professava um liberalismo restrito aos direitos individuais, às instituições clássicas (parlamento, judiciário, partidos) e à economia de mercado. 
Para esses jornais, portanto, e esta observação se aplica especialmente ao Estadão, a relação com a ditadura era um desafio constante. Apoiaram o golpe de 1964 e o reivindicaram como uma revolução legítima, e continuaram a apoiar as ações repressivas voltadas à manutenção da ordem social. E com tal atitude mostraram os limites do seu amor à liberdade, ou seja, mais importante era a ordem social baseada na propriedade privada. ${ }^{2}$ Por isso sua concordância com a repressão ao chamado terrorismo, inclusive a aceitação do uso dessa terminologia que visava deslegitimar a luta armada contra a ditadura.

Entretanto, na pauta política repressiva da ditadura nem tudo agradava à grande imprensa que, significativamente, não se engajou a favor do AI5. Ao contrário, esses jornais viram com maus olhos a escalada autoritária, especialmente porque ela aumentou as restrições à imprensa e incrementou a censura. Mesmo o mais dócil (diante da ditadura) e governista veículo da grande imprensa tradicional, O Globo, aceitou o AI5 como um recurso passageiro e continuou sustentando declarações de fé liberais. Tampouco foi bem vista pela imprensa, notadamente o Estadão, a possibilidade de a ditadura fechar completamente as instituições políticas liberais (parlamento e partidos) - o que esteve em pauta no imediato pós-AI5.

Neste artigo voltamos a atenção para a fase aguda do AI5, com objetivo de analisar seu impacto sobre o Estadão e as estratégias do periódico diante do novo cenário. Oscilando entre a resignação e a ousadia, o jornal tentou interferir nos rumos políticos da ditadura usando seus textos e imagens para influenciar a opinião, tanto da sociedade política como da sociedade civil. Um protagonismo que agravou a vigilância estatal sobre o jornal da família Mesquita que, por isso, foi submetido à censura prévia a partir de setembro de 1972.

Ressalto que neste artigo não se pretende fazer estudo de recepção, embora existam possibilidades interessantes a explorar. Pode-se dizer que a reação do Estado, dos líderes políticos e dos outros veículos da imprensa são uma forma de recepção ao discurso jornalístico. Como tentarei mostrar, esse tipo de recepção/reação foi forte e, às vezes, imediata.

\footnotetext{
2 Em seu pioneiro estudo sobre o Estadão, Prado e Capelato mostraram que o jornal teve atitude semelhante nos anos 1930 , quando apoiou a escalada repressiva do governo Vargas a partir da "Intentona Comunista" de novembro de 1935, que foi utilizada para pavimentar o caminho para a ditadura de 1937. A diferença em relação ao contexto abordado neste artigo é que o jornal não apoiou o golpe de 1937, mas apoiou o golpe de 1964 (CAPELATO; PRADO, 1980).
}

Última observação introdutória. O impacto político das representações da imprensa é tema atual, por razões óbvias. Compreender isso melhor no período da ditadura poderá, talvez, ser útil para pensar os dilemas de hoje.

\section{$* * *$}

O Estadão foi um ator "revolucionário" de primeira hora em 1964, com destaque para o intenso protagonismo do seu proprietário, Júlio de Mesquita Filho, que usou o tradicional editorial (intitulado Notas e informações) para defender seus pontos de vista. O herdeiro de Júlio de Mesquita seguiu a tradição familiar de mobilizar o jornal a serviço de seus ideais políticos, colocando o periódico em posição semelhante a um partido político. Por isso, não surpreende que em 1964, tal como em ocasiões anteriores (CAPELATO; PRADO, 1980), o Estado de São Paulo esteve no fulcro dos acontecimentos políticos.

O Estadão apoiou com entusiasmo o expurgo inicial da ditadura, defendendo uma intervenção dura e rápida, para limpeza do terreno e posterior restauração das instituições liberais. O paradoxo é flagrante, pois defendeu medidas autoritárias com o argumento de que as instituições liberais sairiam fortalecidas ao fim do processo. Porém, os dirigentes do jornal achavam a estratégia coerente, pois condenavam medidas ou leis autoritárias duradouras, temendo que a ditadura se eternizasse. Seguindo a visão favorável a uma "limpeza" rápida e profunda, os donos do Estadão não gostaram que o expurgo de 1964 fosse limitado, por isso estrilaram muito devido à hesitação do governo Castelo Branco em atingir certos líderes, como o governador Ademar de Barros, por exemplo. ${ }^{3}$ Por outro lado, criticaram também quando a ditadura editou outras medidas autoritárias além do Ato Institucional, fiéis à visão de que a legislação excepcional deveria ser limitada e passageira.

Assim, o Estadão discordou do AI2, da nova Constituição de 1967 e da Lei de Imprensa editada naquele mesmo ano. O entusiasmo inicial do jornal foi arrefecendo a partir de 1966 e, no quadro do governo Costa e Silva, que assumiu em 1967, o sentimento em relação à ditadura passou à decepção. Não agradava aos editores do diário o incremento da legislação autoritária, a crescente militarização do Estado e a redução da importância dos civis nos quadros

\footnotetext{
3 Mais sobre a cassação de Ademar de Barros em: (MOTTA 2016).
} 
governamentais. Nesse período (1966-1968), o Estadão cultivou a ideia de que 1964 era resultado de consenso liberal e democrático, passando a acusar a "revolução" de afastar-se dos ideais de 31 de março. Tratava-se, na verdade, de uma disputa com a ala mais à direita da ditadura, composta por nacionalistas autoritários, integristas católicos e fascistas, para quem os valores liberais e a liberal-democracia não importavam tanto. Um embate que continuaria nos anos seguintes.

No decorrer do crítico ano de 1968, o jornal foi se afastando mais do governo Costa e Silva, que além de ser considerado infiel ao espírito de 1964 foi acusado de incompetência na gestão do desafiador quadro político. No dia em que o AI5 foi editado, 13 de dezembro de 1968, Julinho Mesquita escreveu sua última manifestação política no editorial intitulado "Instituições em frangalhos", que levou à apreensão da edição. O texto fazia crítica demolidora do governo Costa e Silva, responsabilizando-o pela crise e pela derrota do pedido para punir o deputado Márcio Moreira Alves. ${ }^{4}$ Segundo Mesquita Filho, o fracassado governo não tinha apoio da opinião pública nem do Congresso e o regime estaria por um fio, em vias de ser desmantelado. A intervenção autoritária no jornal coincidiu com a enfermidade de Mesquita Filho, que parou de escrever os editoriais e morreu poucos meses depois.

O impacto do AI 5, combinado ao afastamento e morte de Júlio de Mesquita Filho provocou mudança importante no jornal. O editorial do Estadão deixou de tratar da política nacional, salvo em casos muito excepcionais. ${ }^{5}$ Os seus textos passaram a abordar apenas a situação internacional, geralmente comentários de tom enfadonhamente anticomunista sobre a Guerra Fria. Seja por repúdio à censura, seja para proteger a empresa de novas ações autoritárias, o fato é que a opinião política do Estadão passou a se expressar em outros textos e por meio de novas estratégias discursivas.

Entre 1969 e 1974, artigos assinados por jornalistas de destaque da empresa, especialmente Fernando Pedreira, Evandro Carlos de Andrade, Flávio Galvão e Carlos Chagas tornaram-se meios para exprimir a opinião política do periódico. Evidentemente, uma

\footnotetext{
4 O Estadão defendia que o deputado merecia punição para desagravar a honra militar (cf. editorial de $5 / 11 / 68$, p. 3) e, com isso, pagava tributo a suas ligações com os meios castrenses. Porém, entendia que o caso não justificava o choque com o Congresso e nem uma crise de tamanhas proporções.

5 Ver editorial de $13 / 07 / 69$ (p. 3) que homenageou a memória de Júlio de Mesquita Filho e explicou a mudança de formato do editorial.
}

análise em detalhe mostraria nuanças e particularidades nos artigos escritos por cada um desses jornalistas. Mas, em linhas gerais, eles seguiram fielmente a linha do jornal, a qual ajudaram a construir: apoio à intervenção militar de 1964 e às medidas para defesa da ordem social, inclusive as repressivas; porém, ao mesmo tempo, recusa a uma ditadura que suprimisse as instituições liberais.

Outro espaço de destaque para a expressão de opiniões políticas foi a coluna "Das sucursais", que saía na mesma página do editorial. Diferente dos artigos opinativos, nesse caso tratava-se de reportagens políticas, raramente assinadas, cujo propósito era comentar informações colhidas junto a fontes parlamentares e lideranças governamentais. Embora o formato de "Das sucursais" apontasse para reportagens e informações objetivas, muitas vezes ela serviu para exprimir opiniões do próprio jornal, travestidas de comentários feitos por entrevistados que nem sempre eram nomeados. Assim, os editores conseguiam passar mensagens políticas afeitas aos valores do jornal, com a sutileza de atribuir tais opiniões a terceiros, na tentativa de evitar a repressão.

O impacto do AI5 se fez presente também nas charges, que passaram a evitar temas mais polêmicos ou que incomodassem o poder. A partir de 13 de dezembro de 1968, a maioria dos desenhos políticos de Hilde e Biganti, que se revezavam na autoria das charges publicadas diariamente no Estadão, se restringiram a temas toleráveis para a ditadura, como o sistema bipartidário, ou a política estadual e municipal. Eventualmente eles publicaram alguns desenhos politicamente mais ousados, como veremos, mas sempre compatíveis com a linha geral do periódico.

Pois bem, com base nos textos da coluna "Das sucursais", nos artigos assinados por jornalistas de destaque, em algumas charges e nos raros editoriais que abordaram o quadro político nacional serão analisados os discursos e atitudes do Estadão em relação à ditadura no período entre o AI5 e o fim do governo Médici. O objetivo é perceber não apenas os temas predominantes no discurso político do diário, mas, também, as estratégias utilizadas para influenciar tanto os leitores como o governo e demais atores do cenário político, em especial no contexto do jogo sucessório que culminou na escolha de Ernesto Geisel.

A primeira observação é que as estratégias discursivas variaram durante o período, devido à pressão exercida pelo Estado autoritário e às oscilações do jornal. Imediatamente após o AI5 o Estadão adotou tom moderado e cordato, certamente por medo de 
provocar as forças de repressão, que haviam mostrado sua disposição ao recolher uma edição inteira do jornal em 13/12/1968. Os textos opinativos desapareceram e foram publicadas apenas reportagens informativas, em tom neutro e cuidadoso. O diário dos Mesquita recuou em relação à sua verve política tradicional e evitou questionar o novo Ato Institucional, do qual discordava. Os editores do Estadão aceitaram o argumento de que criticar o governo pioraria as coisas. Ao contrário de resistir ao AI5, na verdade o jornal fez concessões e se acomodou à situação, na esperança de estimular o governo a usar com moderação os poderes extraordinários de que estava investido. Textos publicados no Estadão chegaram a pedir regras mais claras para a censura, um indício de que pretendiam minorar os seus efeitos para conviver com a nova situação. Porém, é importante registrar, em nenhum momento o jornal concordou com a guinada autoritária e o seu desconforto era evidente mesmo nos textos mais moderados.

Não obstante discordasse do AI5, o Estadão apoiou a pauta repressiva da ditadura quando a esquerda era o alvo. A sutileza da posição ficaria mais clara posteriormente, quando o jornal recobrou a coragem de criticar o governo e postulou que a repressão aos "terroristas" não demandava novas leis autoritárias. Evidentemente, o uso da expressão terroristas, e sem aspas, é revelador da opinião do jornal sobre a esquerda armada. $\mathrm{O}$ repúdio à ameaça revolucionária era tamanho que originou um dos raros editoriais dessa época referidos à situação nacional, embora com viés internacional. Trata-se do "Notas e Informações" de 28/01/69, que atacou de maneira virulenta D. Hélder Câmara por suas críticas ao Brasil no exterior, em palestras que denunciavam a prática recorrente de tortura contra presos políticos. Para o jornal, que procurou desqualificar Câmara acusando-o de ter uma vaidade incompatível com a condição de religioso, a denúncia era mentirosa. Segundo o editorial, no máximo poderiam ocorrer casos isolados de violência, mas não tortura como prática generalizada, pois isso era típico dos países comunistas. Aliás, parte da irritação do editorialista devia-se ao prelado católico ter defendido Cuba e China em seus discursos, atitude inaceitável para o anticomunismo empedernido do Estadão.

Durante o primeiro semestre de 1969, o noticiário político deu destaque ao longo processo de cassações que gerou uma sequência de listas de cidadãos punidos pelo AI5. Para informar sobre o assunto o jornal tentava conseguir informações de bastidores, sempre na expectativa de que a próxima lista de atingidos seria menor do que a anterior. Os textos comentavam - e partilhavam - a angústia dos parlamentares, receosos de perder o mandato e também de que o Congresso, colocado em recesso forçado desde dezembro de 1968, jamais viesse a ser reaberto. Ainda que discretamente, os textos informativos do Estadão torciam pelo fim dos expurgos e pela reabertura do Parlamento.

Em meados de maio de 1969, um texto da seção "Das Sucursais" comentou satisfeito que se vivia o melhor clima político desde a edição do AI5. Sob o título "Chega o tempo da reabertura política", enorme exagero em vista da situação, o texto afirmava que Costa e Silva estava disposto a reabrir o Congresso e restabelecer parte das instituições liberal-democráticas. Sabia-se que o governo retiraria algumas prerrogativas tradicionais do parlamento e que novas punições ainda poderiam ocorrer, mas, dizia o jornal, era preferível um congresso aberto, mesmo que mutilado. ${ }^{6}$

Pela mesma época foi publicada outra matéria importante para perceber as estratégias e a opinião do diário no imediato pós-AI5. Segundo o texto, publicado em 28 de maio de 1969, o governo concordava com a reabertura do Congresso, mas alguns setores desejavam apenas um parlamento decorativo, sem poder real. O texto argumentou que essa opção seria acabrunhante, mas concordava com a necessidade de encontrar fórmulas de meio termo para agradar tanto a ala radical do Estado como os políticos moderados. Não adiantaria esperar uma fórmula romântica, pois se os militares não fossem atendidos haveria risco de nova crise e o país poderia cair em uma ditadura! $!^{7}$ Deixando de lado a patética opinião de que ainda não existia uma ditadura, de qualquer modo é evidente a preferência e uma discreta pressão - do jornal por uma forma de governo mais liberal.

Com o afastamento de Costa e Silva e a ascensão ao poder da Junta Militar, no início de agosto de 1969, o pessimismo voltou e com ele o medo que a ditadura eliminasse o pouco que restara das instituições liberais e não reabrisse o Congresso, uma reabertura esperada - e demandada - desde março. A ansiedade e a tensão pioraram logo em seguida, com o sequestro do embaixador norte-americano por um comando guerrilheiro, que fortaleceu os setores da ditadura contrários ao abrandamento da repressão. Diante do novo quadro o diário abandonou o sonho de postular

\footnotetext{
Edição de 18/05/69, p.3.

7 “Das sucursais", edição de 28/05/69, p. 3
} 
um político civil para suceder a Costa e $\mathrm{Silva}^{8}$ e recebeu com bons olhos a escolha do general Médici para a presidência, considerada alternativa melhor do que a continuidade de uma Junta Militar. Além disso, acreditava-se que Médici era respeitado tanto pelo grupo costista como pelo castelista, podendo unir o Exército e governar com estabilidade. A visão do Estadão sobre Médici ficou mais otimista após pronunciamentos iniciais do general que, embora oblíquos, foram entendidos como compromisso de restabelecimento da democracia. A reabertura do Congresso no mesmo mês de outubro, para confirmar e legalizar a eleição de Médici, previamente escolhido pelos comandantes militares, gerou alívio e otimismo na imprensa liberal.

No entanto, as boas expectativas com Médici logo se dissiparam quando ficou claro que, embora autorizados a funcionar, o Congresso e os partidos teriam apenas papel decorativo. Por isso, o tom pessimista voltou a dominar os discursos do jornal nos meses iniciais de 1970. Um exemplo é o texto "Não se entrevê a abertura política", publicado em 28/2/70 na coluna "Das Sucursais". O tom da matéria é de lamento, pois declarações recentes de Médici decepcionaram quem interpretara em seus discursos iniciais o compromisso de entregar ao sucessor um país em pleno regime democrático. Ele havia dito, na verdade, que esperava faze-lo, mas não se tratava de um compromisso. De acordo com o texto, poucos observadores ainda acreditavam nessa possibilidade.

Algumas charges publicadas nesse período bateram na mesma tecla e contribuíram para divulgar as opiniões do jornal, às vezes com críticas mais ousadas, embora metafóricas. No fim de janeiro de 1970, Biganti abordou a decepção com as expectativas não cumpridas por Médici mencionando o significado do AI5 (27/1/70). A charge (Figura 1) mostra um passarinho frágil e tenro que representa a redemocratização, cujo voo livre é impedido pelo enorme peso do AI5. Destaca-se a desproporção entre o tamanho do AI5 e o pássaro, um recurso para enfatizar o peso do instrumento repressivo.

Para propagar valores liberais e estimular o governo Médici a evitar ações autoritárias mais duras, o Estadão usou vários recursos discursivos. Além de charges e textos que comentavam tais valores positivamente, outra estratégia foi ressaltar personagens históricos

\footnotetext{
8 Pouco antes da doença de Costa e Silva, o jornal especulou o nome de um político civil para sucedê-lo: "Milton Campos é a possível solução", 10/07/1969, p. 3.
}

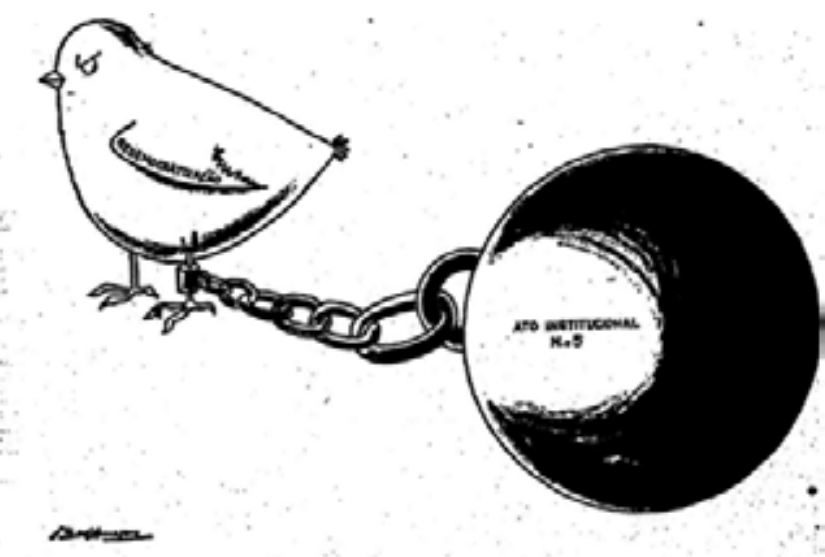

Figura 1. O Estado de São Paulo, 27/01/1970, p. 4. Biganti.

associados à causa da liberdade. Por isso alguns textos homenageavam figuras como José Bonifácio Andrada e Ruy Barbosa, por exemplo, ou o Manifesto dos Mineiros. ${ }^{9}$ Daí também o investimento em retratar o primeiro presidente da ditadura, Castelo Branco, como um herói liberal, deixando de lado as críticas a ações autoritárias do seu governo, como o AI2 e a Lei de Imprensa. Mesmo D. Pedro I se prestou aos propósitos dessa retórica liberal. Por exemplo, na edição de 28/8/71 saiu uma matéria com título nada ingênuo: "Há 150 anos, D. Pedro abolia a censura no país". ${ }^{10}$

Por falar em censura, no período imediato ao AI5 o Estadão buscou acomodar-se com o controle estatal e não se importou muito com a censura afeta à "moral e bons costumes". Desde janeiro de 1970 estava em vigor o decreto 1.077 , que permitia a apreensão de livros e periódicos, limitando, portanto, as garantias constitucionais de liberdade de imprensa. Porém, o decreto proibia formalmente apenas manifestações contrárias à moral e aos bons costumes, sem mencionar opiniões e ideias políticas. O entendimento do jornal era que o decreto 1.077 restringia-se à defesa da moral $\mathrm{e}$ em alguns textos e charges mostrou concordância com esse tipo de censura. Entretanto, em meados de 1970, quando alguns líderes propuseram ampliar a legislação censória para além da defesa da moral, o jornal sentiu-se ameaçado e reclamou, tanto nos discursos visuais como verbais.

Uma das manifestações mais significativas foi o artigo assinado pelo jornalista Flávio Galvão em 17/5/70, intitulado "Espírito de censura". Aproveitando

\footnotetext{
9 Edição de 24/10/73, p. 3, "Das sucursais": "O Manifesto Mineiro mantém a atualidade".

${ }^{10}$ Outra estratégia era criticar a ditadura em outros países. Em 28/10/69 (p. 3), um editorial comentou a situação em Portugal e criticou com dureza a ditadura e falta de liberdade naquele país.
} 
um episódio na Câmara dos Deputados, cujo presidente censurou um discurso do MDB nos Anais da instituição, Galvão criticou o incremento da censura de maneira geral. Mobilizando argumento caro ao Estadão, o jornalista atacou a censura por ferir não somente a Constituição, mas também o espírito da "Revolução liberal e democrática de março de 1964". Simultaneamente, os chargistas do Estadão usaram recursos visuais para bater na mesma tecla. Em desenho publicado três dias antes do texto de Flávio Galvão $(14 / 5 / 70)$, Biganti abordou a censura retomando a metáfora do pássaro, que desta vez representava a liberdade de imprensa, efeito sugerido pela presença da caneta (Figura 2). A liberdade está engaiolada graças à censura prévia (a expressão está escrita no cadeado), que aparece na charge se sobrepondo à Constituição. Hilde tratou do mesmo tema dois meses depois, com um discurso mais direto. Na charge (Figura 3) publicada em 10/07/70, dois homens (intelectuais ou jornalistas, presumivelmente) representando os periódicos e os livros aparecem amarrados pela censura prévia, ao que reagem demonstrando expressões faciais igualmente "amarradas".

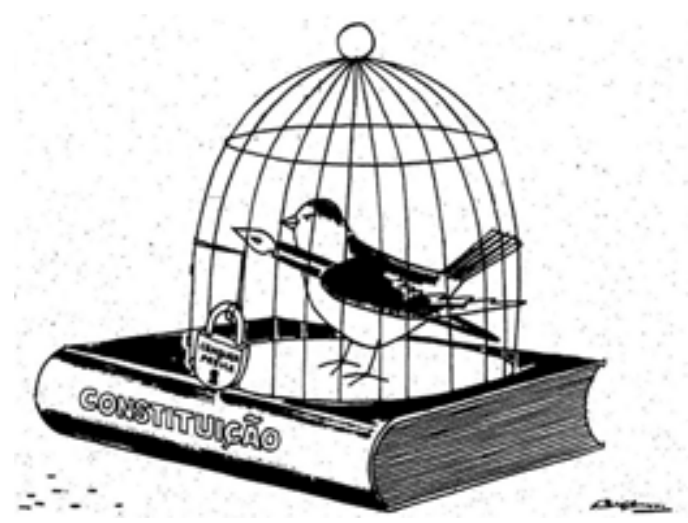

Figura 2. O Estado de São Paulo, 14/05/1970, p. 4. Biganti.

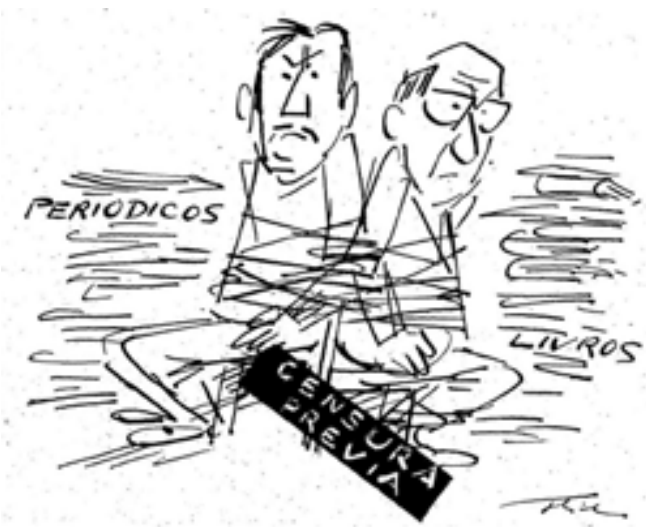

Figura 3. O Estado de São Paulo, 10/07/1970, p. 4. Hilde.
Porém, a crítica a algumas facetas autoritárias do período Médici não significou rompimento com a ditadura. O jornal continuou na linha da "revolução" e apoiando a repressão ao "terrorismo", especialmente quando o Brasil era alvo de críticas internacionais. Por isso, o jornal publicou irado editorial (em 22/5/70) quando o Estado norte-americano cortou 150 milhões de dólares de créditos para o Brasil, por pressão de setores preocupados com o aumento da violência política. O editorial atacou com especial virulência o senador Ted Kennedy, considerado o líder da campanha, a quem chamou, sutilmente, de bêbado. Segundo o editorial, o jornal não concordava com os rumos políticos do governo Médici e preocupava-se com certas correntes totalitárias que tentavam forjar uma ideologia para a revolução. Porém, achava que a decisão norte-americana seria contraproducente e só agradaria aos totalitários de esquerda e direita, prestando um desserviço à democracia.

Entretanto, o Estadão discordava de que a defesa da ordem demandasse mais legislação autoritária. Ao contrário, seus textos diziam que a repressão à ameaça revolucionária não precisava de novas restrições às instituições liberais. Tal opinião ficou mais enfática com o declínio das ações armadas da esquerda, em especial após as mortes emblemáticas dos líderes Carlos Marighela e Carlos Lamarca. Por exemplo, um texto de dezembro de 1970 intitulado "Terror: govêrno deve ser sereno" comentou a opinião de político arenista sobre o sequestro do embaixador suíço. O comentário, na verdade, era a opinião do próprio jornal atribuída à suposta fonte: o terrorismo era uma praga e precisava ser reprimido, mas, não ameaçava o regime e nem deveria tirar a serenidade do governo. ${ }^{11}$

Importante referir que as posições liberais do Estadão implicavam também a economia. Preocupava ao jornal o aumento da interferência do Estado na economia e os fundamentos nacionalistas de algumas dessas ações. Visível desde o governo Costa e Silva, o desenvolvimentismo nacionalista e autoritário se incrementou no período Médici, provocando a clássica crítica liberal sobre os males do estatismo em contraposição à eficiência da iniciativa privada. Como todas as críticas ao governo nesse período o tema foi tratado com cautela, mas o jornal não deixou de registrar sua discordância, mais uma vez com bom afinamento entre textos e charges.

\footnotetext{
$\overline{11}$ Edição de 16/12/70, p.3.
} 
Os textos criticaram a "deriva nacionalista" da revolução, ${ }^{12}$ receberam com má vontade projetos de integração nacional como a Transamazônica, atacaram a declaração de soberania sobre 200 milhas náuticas, considerada economicamente pouco vantajosa ${ }^{13}$, e discordaram da implantação do Programa de Integração Social (PIS), pois contrariava as doutrinas liberais que inspiraram a "revolução". ${ }^{14}$ Algumas charges deram representação visual ao tema, como um desenho de Biganti (26/8/70) que mostrava a burocracia pública retratada como uma velha senhora glutona sonhando em encher a barriga com o PIS, desenhado como um assado suculento.

Alguns textos do jornal atribuíram o incremento do nacionalismo e do intervencionismo estatal à estratégia de atrair apoio popular, já que o combate à subversão e à corrupção não empolgavam mais a população. Nesse ponto nota-se um paradoxo da ditadura. Embora as eleições tivessem pouco valor, já que não definiam o perfil dos governantes e os parlamentares não tinham poder efetivo, a ditadura necessitava atrair o voto popular. Qualquer regime autoritário, mesmo os que suprimem totalmente eleições e instituições representativas governam com um olho na opinião popular. A repressão nunca é suficiente para garantir estabilidade. No caso de uma ditadura que fazia eleições periódicas para deputados, senadores, vereadores e prefeitos, o problema da popularidade era mais desafiador. Uma derrota eleitoral causaria constrangimento e mal-estar, por isso, o nacionalismo ufanista e as medidas toscas na direção de suposta democracia social são explicáveis, em parte, pela necessidade de buscar popularidade.

Porém, há que considerar também as inclinações ideológicas dos atores políticos, pois a popularidade poderia ser buscada com outras estratégias. Desde seu início a ditadura foi apoiada por arco direitista amplo que, além dos liberais, incluía conservadores, fascistas e nacionalistas autoritários. O primeiro governo militar, chefiado por Castelo Branco, foi o mais influenciado pelos liberais, mas, a partir de Costa e Silva e, especialmente com Médici, as outras correntes ampliaram seu espaço. Essa deriva nacionalista e estatista criticada pelo Estadão afetou não apenas a economia, mas teve uma contraparte ideológica, pois algumas figuras do governo Médici ensaiaram enterrar de vez o liberalismo político.

\footnotetext{
${ }^{12}$ Texto de Fernando Pedreira em 14/5/70, p. 4.

${ }^{13}$ Edição de 10/6/71, "Notas e informações", p. 3.

${ }^{14}$ Edição de 23/8/70, "Notas e informações" (com o título "Estados
} Moloch"), p. 3
O tema foi mencionado em editorial citado há pouco, que tratou do corte de créditos norte-americanos para o Brasil. O editorialista mostrou preocupação com correntes totalitárias que procuravam forjar uma ideologia para a "revolução". A questão foi tratada em diferentes textos e charges, sempre mobilizando o argumento do Estadão de que a "revolução" não deveria sair do leito liberal. Do ponto de vista da direita conservadora, que tinha no governo figuras de proa como Alfredo Buzaid, ministro da Justiça, e Filinto Müller e Raimundo Padilha, líderes parlamentares de Médici (sem falar nas figuras que comandavam as Forças Armadas), o momento era propício para definir uma doutrina política para a ditadura alternativa ao liberalismo. Durante o período Médici falou-se muito em doutrina ou modelo político para a "revolução", em debates que circularam nos corredores do poder e na Escola Superior de Guerra, esparsamente noticiados pela imprensa. O movimento incomodou ainda mais à opinião liberal por ser identificado com tentativa de reorganização dos antigos integralistas, que pareciam ter ganhado mais espaço no governo. Além de Plínio Salgado, que ocupava cadeira de deputado pela ARENA e mantinha certa influência, outros ex-integralistas tiveram proeminência política, como os já mencionados Raimundo Padilha e Alfredo Buzaid. A propósito, no artigo citado há pouco em que criticou a censura, o jornalista Flávio Galvão afirmou, em metáfora pouco sutil, mas, politicamente eloquente: "no momento voltam a cacarejar as galinhas verdes".

Significativamente, coube a Buzaid papel de destaque nas tentativas de criar uma doutrina ou conceito político para a ditadura, que implicaria forma de democracia não liberal. $O$ fundamento era que a democracia liberal estava ultrapassada, como afirmara um jurista de direita, ${ }^{15}$ sendo necessário encontrar um modelo adequado à realidade brasileira. Falava-se na necessidade de um poder executivo forte, assim como de uma democracia social, vocacionada para a justiça social e para harmonizar capital e trabalho. Como se percebe, tratava-se da recuperação de velhos conceitos da direita integralista, nacionalista e corporativista, reinterpretados à luz da ditadura dos anos 1970. O próprio Médici fez menção à busca da democracia social e da defesa de interesses coletivos, mas, com o cuidado de acenar também para os valores liberais. ${ }^{16}$

\footnotetext{
${ }^{15}$ Edição de 7/6/72, p. 5: "Jurista anuncia o fim da democracia liberal".

${ }^{16}$ Edição de 1/04/70, p.3. Isso ajuda a entender a famosa declaração do presidente, no contexto do "milagre", de que a economia ia bem, mas o povo nem tanto. É porque ele estava influenciado pelas visões da direita conservadora, que se preocupava com os efeitos do capitalismo sobre o aumento da pobreza.
} 
Se o projeto não foi consistente e nem logrou romper totalmente com o liberalismo, parte do seu insucesso deve ser atribuído à reação da ala liberal da ditadura, com destaque para o Estadão. Vários textos abordaram o tema, defendendo a tradição liberal brasileira e a democracia baseada na liberdade e nos direitos individuais. ${ }^{17}$ Assim, o empenho liberal do Estadão nesse período deve ser compreendido, também, sob o pano de fundo da disputa com setores da direita conservadora que tentaram conferir à ditadura uma doutrina ou ideologia autoritária.

As divergências políticas e ideológicas do Estadão em relação a certos rumos da ditadura explicam um aspecto marcante nos textos publicados no período: a falta de empolgação com o chamado milagre econômico. Pelo menos nos textos de natureza política não se vê a exaltação típica da fase do milagre. Nesta pesquisa não foram verificadas todas as seções do jornal e tampouco conferimos se foi publicada propaganda oficial. Porém, mesmo que o periódico tenha publicado matérias pagas de caráter ufanista, seus textos políticos diziam outra coisa. Por exemplo, em texto intitulado "País bate recordes de desenvolvimento" afirmouse que era ótimo o PNB chegar a $11 \%$. Mas não se notou euforia, ao contrário, pois o texto apontou alguns problemas e equívocos cometidos pelo governo. Significativamente, afirmou-se que o sucesso se devia a ações do governo Castelo Branco, como a negar todo o crédito ao governo Médici. ${ }^{18}$

A discordância em relação ao nacionalismo e ao intervencionismo estatal ajuda a entender a frieza do Estadão diante do milagre. Ademais, o jornal temia que o sucesso econômico fortalecesse o projeto político da direita conservadora e corporativista, que poderia usar a popularidade decorrente do "milagre" para conferir fundações mais sólidas à ditadura. Daí o argumento do jornal de que, ao contrário de legitimar a escalada autoritária, o crescimento econômico abria oportunidade de retorno à democracia. $\mathrm{Na}$ visão do jornal, partilhada por outros setores, o sucesso do "milagre", em combinação com outro fator favorável, a derrota da guerrilha, criava o cenário ideal para a redemocratização. $\mathrm{O}$ tema foi trabalhado em inúmeros textos, muitas vezes apresentado aos leitores na forma de comentários atribuídos a políticos anônimos. Para exemplificar, vou citar apenas os títulos de duas reportagens publicadas na seção "Das Sucursais",

\footnotetext{
${ }_{17}$ Ver textos publicados nas seguintes edições: $29 / 3 / 70$, p. 4 , 4/9/71, p. 3, 4/2/72, p. 4 e $9 / 6 / 72$, p. 4.

${ }_{18}$ Edição de 28/5/71, p. 3.
}

que são esclarecedores quanto ao seu conteúdo: "Êxito econômico pode ensejar a reabertura" e "Desenvolvimento cria clima para abertura". ${ }^{19}$

\section{Na sucessão de Médici, o Estadão aumenta as apostas}

No período final do governo Médici, o Estadão intensificou sua campanha liberal e forçou os limites da tolerância estatal, que reagiria submetendo o jornal à censura prévia. Os dirigentes do periódico entenderam que a sucessão era momento decisivo na luta por seus valores e interesses, ou ao menos para impedir a vitória de seus adversários. Como percebiam que os nacionalistas e corporativistas haviam ganhado espaço com Médici, não é difícil compreender porque resolveram correr riscos no processo sucessório. Temiam que seus adversários se consolidassem no poder e influenciassem o novo governo também.

O tema era delicado, pois o Sistema - expressão que o jornal começou a usar por volta de 1971 para designar o grupo no poder, por isso usando letra maiúscula - não queria saber de debate sucessório e ordenou silêncio sobre o assunto. Em outubro de 1971 saiu uma reportagem de título "Problema sucessório só no próximo ano". Segundo o texto, o governo desejava conter as especulações sobre sucessão até meados de 1972, devido a um cálculo estratégico. A ideia era que no segundo semestre de 1972 Médici alcançaria o auge da popularidade, pelos resultados econômicos e também pelos efeitos das festas do sesquicentenário, então, teria condições ideais para conduzir com calma o problema sucessório. "Hora oportuna para o presidente Médici cumprir o compromisso da restauração democrática", comentava o mesmo texto do Estadão, sem perder a oportunidade de marcar a posição do jornal. ${ }^{20}$

Mas o que significaria democracia ou democratização na perspectiva da equipe do jornal? Certamente havia nuanças e diferentes pontos de vista entre os proprietários da empresa e os jornalistas. De qualquer forma, o seu horizonte não ultrapassava o liberalismo e tampouco implicava ruptura com os militares. Um artigo de Carlos Chagas publicado em maio de 1972 ("A vez e a hora da democratização") é revelador das

\footnotetext{
${ }^{19}$ Respectivamente, edições de 24/9/71, p. 3 e 26/6/71, p. 3.

${ }^{20}$ Edição de 20/10/71, p. 3. Posteriormente, o Sistema determinou que a sucessão só seria tratada publicamente no segundo semestre de 1973, ou seja, às vésperas da eleição indireta do futuro presidente. Sobre as comemorações oficiais do Sesquicentenário ver: (CORDEIRO, 2015).
} 
visões divulgadas pelo Estadão. No texto, ele elencou os sucessos econômicos do governo para reiterar a opinião de que não havia melhor momento para redemocratizar o país. Ao contrário dos temores de alguns "revolucionários", ele afirmou que isso não significaria trair o movimento e retornar à situação pré1964. Chagas defendeu o fortalecimento do Congresso e o estabelecimento de regras jurídicas estáveis, claras e dissociadas do arbítrio. Porém, isso não significava devolver o poder imediatamente aos civis ou reduzir o papel dos militares e dos técnicos. ${ }^{21}$ A sugestão era institucionalizar e normalizar a "revolução", aproximando-a da tradição liberal. Uma democracia limitada, portanto.

Em dezembro de 1972, momento em que o Estadão já estava sob censura prévia, Chagas voltou ao tema em termos semelhantes:

Institucionalização, democratização ou volta ao Estado de direito não serão jamais eventos antirevolucionários, se conduzidos pela maioria revolucionária dentro das ideias e da inspiração do movimento de 31 de março. Institucionalizar não significa ameaçar nem fazer voltar o passado, senão ordenar e restabelecer determinados princípios básicos que devem reger as sociedades democráticas. (...) Para que a Revolução continue com duração ilimitada no tempo, por força de suas ideias e de sua inspiração, é imprescindível que o seu processo flua para a normalidade. (O Estado de São Paulo, 15/12/1972, p. 5).

Armado com tal visão liberal da democracia, com inclinação para aceitar compromissos com as forças autoritárias, o Estadão procurou manter-se informado e informar os leitores sobre o debate sucessório. Embora reconhecesse sua frágil capacidade de influir nas decisões palacianas, o periódico agiu como uma fonte de pressão relevante. E o governo pensou o mesmo, de outro modo não teria razão para punir com a censura as ousadias do jornal.

Já em janeiro de 1972 o Estadão contrariou a determinação oficial e divulgou que um dos nomes mais fortes para o governo era Ernesto Geisel, então presidente da Petrobrás. O assunto era privativo do governo, como registrava provocativamente o título de uma das reportagens, mas era tratado nas páginas do jornal mesmo assim. ${ }^{22}$ Em meados de 1972 o jornal

${ }^{21}$ Edição de 12/5/72, p. 5.

${ }^{22}$ Edições de 21/1/72, p. 4 e 2/5/72, p. 3. ousou mais, publicando reportagem que apontava a candidatura Geisel como uma opção forte. O texto especulava que Geisel poderia aglutinar os castelistas e também as esperanças de alguns políticos civis marginalizados pelo Sistema. ${ }^{23}$

Apesar da cautela do jornal em evitar identificação com Geisel é significativo que na mesma edição publicaram textos de destaque sobre Castelo Branco, cujos restos mortais estavam sendo transferidos para seu estado de origem, o Ceará. Um dos textos tinha o seguinte título "Ele inspira o Brasil de hoje". Alguns dias depois, quando os despojos de Castelo e de sua esposa chegaram ao Ceará, o jornal publicou mais uma página inteira de elogios ao ex-presidente, insistentemente retratado como um grande democrata. ${ }^{24}$ Essa estratégia discursiva baseava-se no esquecimento das medidas autoritárias de Castelo Branco, que o próprio jornal criticou na época de seu governo, e corroborava a versão insistentemente acalentada sobre as origens liberais de 1964.

A tentativa do Estadão de influenciar a sucessão é visível em várias manifestações sobre democratização, institucionalização e abertura, bem como em textos que especulavam sobre a possibilidade de Ernesto Geisel avançar a pauta da redemocratização. ${ }^{25} \mathrm{~A}$ estratégia passou também pela divulgação da opinião de políticos, militares ou intelectuais que, embora ligados à ditadura tinham inclinações liberais e achavam o momento adequado para uma distensão política. Nos meses de junho a setembro de 1972, fase de intensas articulações sucessórias, algumas figuras com esse perfil começaram a defender publicamente que era o momento de repensar o quadro político, e o Estadão tratou de reverberar a sua opinião. Por exemplo, Gilberto Freyre fez algumas conferências pelo país, inclusive na Escola Superior de Guerra, com cobertura do Estadão. E Roberto Campos publicou artigo no jornal em que afirmava, entre outras coisas, que a "Revolução" havia obtido total sucesso econômico, com base na aliança entre tecnocratas e militares. Mas, de acordo com ele, seria preciso aceitar críticas, conviver com a oposição e valorizar os políticos e as instituições, de outro modo haveria o risco de chegar a um beco sem saída. ${ }^{26}$

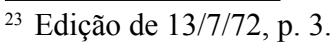

${ }^{24}$ Edição de $17 / 7 / 72$, p. 5.

${ }^{25}$ Cf. especialmente: "Sucessão: chave da normalização" (7/7/72, p.3), "Políticos insistem na democratização" (19/7/72, p. 3) e "Problema sucessório assume maior vulto" (6/8/72, p. 3). Em meio às articulações de bastidores alguns líderes propuseram a reeleição de Médici, mas a ideia não prosperou.

${ }^{26}$ Edição de 23/08/72, p. 4. Campos publicava regularmente no jornal textos de análise econômica. $\mathrm{O}$ fato de que tenha resolvido
} 
Dois dias após a publicação do artigo de Campos, a redação do Estadão foi varejada por policiais em busca de um artigo bomba que faria a revelação oficial da candidatura de Ernesto Geisel (GASPARI, 2003 , p. 210). Nada encontraram, havia sido um boato. Porém, o episódio é revelador da tensão que o problema sucessório gerava nas forças governistas. Três semanas depois, o jornal publicou uma entrevista que deslanchou o mecanismo da censura prévia. $\mathrm{O}$ entrevistado era o marechal Osvaldo Cordeiro de Farias que, tal como o próprio Campos, tivera forte ligação com Castelo Branco. Aliás, a entrevista continha fartos elogios a Castelo Branco, além de algumas críticas a Costa e Silva e sugestões para que o governo revisasse certas punições políticas e fortalecesse o poder legislativo. ${ }^{27}$ Parece que foi a gota d'água. Na sequência da publicação da entrevista de Cordeiro, o Estadão recebeu uma ordem do ministro da Justiça, entregue em 15/09/72, proibindo publicar textos sobre abertura política, sucessão presidencial e menções desfavoráveis à situação econômica. A ordem especificava que a proibição valia inclusive para exministros dos governos militares (o caso de Cordeiro e de Roberto Campos) e, finalmente, proibia uma entrevista ainda não publicada de Campos.

A intenção era certamente enquadrar o Estadão na praxe da censura informal ou autocensura, que era a regra na maioria dos jornais. ${ }^{28}$ Porém, Ruy Mesquita, um dos herdeiros de Júlio Mesquita Filho, irritou-se e enviou carta irada ao ministro da Justiça Buzaid dizendo ter vergonha pelo fato do governo degradar o Brasil à situação de república de bananas, seguir pelo rumo do caudilhismo militar e trair os ideais de Castelo Branco. ${ }^{29}$ Mesquita não disse claramente que desobedeceria às ordens, mas sua ousada carta foi motivo suficiente para a ordem de submeter o jornal à censura prévia.

Os efeitos da censura prévia sobre o Estadão são claramente visíveis a partir de 19 de setembro de 1972,

tratar de política nesse contexto é significativo. Os diplomatas norte-americanos, observadores atentos, comentaram que o texto de Campos tinha notável importância e o associaram à movimentação de G. Freyre, interpretando que setores liberais da ditadura estavam insatisfeitos com os seus rumos políticos. Telegramas da Embaixada dos EUA e do Consulado dos EUA em SP, em 22/06/72 e 1/09/1972. RG 59, caixa 2131, pasta 2, National Archives and Records Administration (Nara) II.

${ }^{27}$ Edição de 13/9/72, p. 4.

${ }^{28}$ As ordens de censura chegavam às redações por bilhetes ou por mensagens telefônicas. Sobre autocensura na imprensa ver: SMITH, 2000, p. 135-166.

${ }_{29}^{29}$ A ordem do Ministro da Justiça e a resposta de Mesquita encontram-se em RG 59, caixa 2131, pasta 2, Nara II). Também abordaram o episódio: AQUINO (1999, p. 58-59) e GASPARI (op. cit.). quando começou a praxe de publicar textos anódinos ou esdrúxulos no lugar das matérias políticas cortadas. Inicialmente, os editores publicaram cartas de leitores em substituição aos textos cortados e, em um segundo momento, passaram a publicar receitas culinárias e trechos de poemas, muitas vezes de Camões, mas também de alguns poetas menos clássicos.

Com a censura prévia o tema sucessório desapareceu momentaneamente do jornal, assim como a cobrança da redemocratização. Pior, a censura vetou textos que noticiavam ações violentas de agentes públicos e a prisão de algumas pessoas, assuntos que às vezes eram publicados no Estadão e ajudavam a proteger as vítimas contra violências mais graves. As reportagens continuaram a comentar o quadro político, especialmente os partidos, mas sumiram os artigos de opinião política, bem como as charges que abordavam temas sensíveis.

Porém, dentro em pouco voltaram as demandas liberalizantes, ainda que de maneira discreta, como um artigo de Carlos Chagas no fim de novembro de 1972 que lembrava, mais uma vez, as promessas de Médici de redemocratização. Alguns títulos de artigos publicados em Das Sucursais no mesmo período são suficientes para mostrar que a pregação liberal foi discretamente retomada na virada entre 1972 e 1973: "O futuro depende de renovação e abertura" e "Classe política vê sinais de distensão". O tema da sucessão foi evitado, por medo da censura, mas aparecia de maneira eufemística, como no último artigo, que afirmou que o anúncio do nome do presidente da Petrobrás para o ano seguinte seria momento chave. ${ }^{30}$ Data dessa fase a construção da imagem do poder judiciário como um baluarte liberal, com textos que exaltavam declarações ou ações de juízes em defesa dos direitos dos cidadãos e das liberdades fundamentais. ${ }^{31}$

A dinâmica da censura nesse período foi pendular, pois algumas edições foram muito cortadas enquanto outras parece não terem sido lidas com atenção pelos agentes policiais. É o que explicaria a publicação de textos mencionando a censura sofrida pelo próprio jornal. No dia $21 / 3 / 73$, por exemplo, uma reportagem sobre o debate parlamentar transcreveu trechos da fala do deputado federal Fernando Lyra em que ele disse estranhar, na leitura do Estadão do dia anterior, o fato de cartas de leitores serem publicadas no lugar do noticiário político. E o deputado afirmou, ainda,

\footnotetext{
${ }^{30}$ Respectivamente $24 / 11 / 72$, p. 4 , 28/1/73, p. 3 e $2 / 2 / 73$, p. 3 .

${ }^{31}$ Edição de 10/2/73, p. 4: "O STF é o depositário dos valores da Nação".
} 
conforme a transcrição do jornal: “A censura está aí. Nada se pode denunciar."

Em maio e junho de 1973, as disputas internas ao Sistema se esclareceram e o Estadão sentiu alívio ao perceber que os rumos da sucessão seriam favoráveis. No texto "Renasce a esperança da institucionalização" nota-se tom otimista, quase a dizer que a campanha do jornal trouxera bons frutos. A reportagem comentava declarações anônimas de lideranças políticas de que o Sistema fora convencido da necessidade de retirar o país do impasse institucional existente desde 1968. Não é que haveria redemocratização rápida, alertava o texto, mas os donos do poder teriam decidido finalmente começar um processo paulatino nessa direção. ${ }^{32}$

A chave de tudo, claro, era a sucessão presidencial. Em meados de junho de 1973 o Estadão anunciou, finalmente, que o novo presidente seria Ernesto Geisel, uma notícia que setores do governo pretendiam segurar até setembro. $\mathrm{O}$ jornal dedicou uma página e meia a Geisel, então figura pouco conhecida pelo público, e adotou um tom genericamente simpático ao falar da sua vida e carreira. Alertas, os censores de plantão cortaram dois trechos das reportagens: uma passagem que apontava o desconforto de Geisel pela censura perseguir "um só jornal" e a afirmação de que o futuro presidente fora contra a candidatura de Costa e Silva. ${ }^{33}$ Uma reportagem publicada na mesma edição comentou opiniões de políticos sobre o significado da escolha de Geisel e o tom foi otimista, devido a sua conhecida ligação com Castelo Branco, mas cauteloso, pois ele era candidato do Sistema e poderia manter tudo inalterado.

Vários textos nas semanas seguintes exploraram o mesmo tom, combinando expectativa positiva com cautela. Os títulos das matérias são eloquentes: "Os perigos de uma esperança exagerada", "Geisel está decidido a não avançar sinais", "Geisel não foi além do que já se previa" e "Mudanças de Geisel só depois de um ano". ${ }^{34}$ As reportagens comentavam que nos seus pronunciamentos públicos Geisel nada prometia, para não criar expectativas na oposição nem provocar mal-estar nos setores conservadores. A estratégia era gradualista, pois o futuro presidente queria evitar problemas enfrentados por seus antecessores que, no seu modo de ver, agiram sem cautela na busca da normalização e enfrentaram crises graves, redundando

\footnotetext{
32 "Das sucursais", edição de 5/5/73, p. 3

33 19/6/73, p. 6 .

${ }^{34}$ Respectivamente, edições de (sempre à página 3): 21/6/73, 23/6/73, 18/9/73 e 19/9/73
}

no AI2 e no AI5. ${ }^{35}$ De qualquer modo, a orientação distensionista de Geisel era confirmada pela escolha de assessores ligados ao castelismo (como Golbery do Couto e Silva) e pela aproximação com figuras da ala liberal da ditadura, como Paulo Egídio, Aureliano Chaves, Cordeiro de Farias e Luiz Vianna Filho.

Os textos opinativos e as reportagens mostram que o Estadão teve uma compreensão acurada do novo quadro a ser iniciado com a escolha de Geisel. Não havia certeza sobre os rumos políticos e nem se descartava novas ações autoritárias, porém, os objetivos distensionistas do futuro presidente foram bem compreendidos. E o Estadão se considerava um dos atores responsáveis por criar condições favoráveis à distensão que, afinal, teria mais percalços que o esperado.

Seja como for, e significativamente, o jornal dos Mesquita acabou se livrando da censura prévia cerca de um ano após a posse de Geisel, em janeiro de 1975. Os editores comemoraram a mudança voltando a dedicar o editorial "Notas e Informações" a questões políticas nacionais. No editorial que registrou com satisfação o fim da censura prévia sobre o jornal, os donos do Estadão manifestaram reconhecimento pela atitude do governo Geisel. Porém, advertiram que a luta pela causa liberal continuava. ${ }^{36}$

\section{Considerações finais}

No início dos anos 1970 a ditadura parecia viver o seu auge, já que tinha um presidente popular, um projeto econômico aparentemente vitorioso e havia desbaratado as forças de oposição. No entanto, discordâncias fervilhavam entre os diferentes grupos que sustentavam o Estado autoritário, levando segmentos liberais a campo para influenciar a sucessão presidencial e evitar o predomínio da direita conservadora. Fiel aos preceitos do liberalismo clássico, o Estadão temeu que a ala mais à direita da ditadura, defensora do nacionalismo e do intervencionismo estatal tivesse sucesso em um projeto de democracia autoritária que ela chamou democracia social ou nova democracia. Assim, o jornal negou apoio a uma ideologia autoritária mais consistente para a ditadura e cobrou respeito ao que considerava os verdadeiros ideais de 31 de março.

O Estadão foi ator político importante na campanha para dar um sentido liberal ao golpe de 1964. Se no

\footnotetext{
35 13/11/73, p. 3.

${ }^{36}$ Edição de 19/01/1975, p.3, intitulada, significativamente, "Voltamos".
} 
front da economia ele não alcançou deter o aumento da intervenção estatal, no campo político sua pressão contribuiu para as ambiguidades da ditadura brasileira, que manteve algumas instituições liberais e, sobretudo, foi incapaz de construir uma ideologia autoritária que empolgasse além dos círculos da direita conservadora. O lema desenvolvimento com segurança ofereceu uma ligadura para os grupos heterogêneos que apoiaram a ditadura. Porém, não constituiu uma ideologia mobilizadora capaz de suprimir as instituições e valores liberais. A propósito, alguns textos do Estadão defenderam que o lema da "revolução" na verdade seria um tripé: desenvolvimento, segurança e democracia. $\mathrm{O}$ jornal empenhou-se em divulgar tais valores notadamente no contexto da sucessão de Emílio Médici, na expectativa de que o futuro presidente abraçasse o projeto de institucionalizar ou normalizar a ditadura, o que para o periódico significava fortalecer as instituições liberais.

Voltando à questão dos comportamentos diante da ditadura, não se pode dizer que o Estadão resistiu. Ao contrário, ele foi um aderente de primeira hora, um ator "revolucionário" que ajudou a instalar e manter os militares no poder. $\mathrm{O}$ fato de em certos momentos ter batalhado para trazer a ditadura mais perto de seus ideais não implica resistência. No máximo, pode-se dizer que em certos momentos o periódico resistiu à censura, porém, isso não significa resistir à ditadura. Além do mais, às vezes a estratégia foi de acomodação com a censura, na tentativa de suavizar os seus efeitos.

Em suma, o Estadão trabalhou pela manutenção de algumas instituições liberais e para fechar o caminho à direita conservadora. Com isso, contribuiu para conferir à ditadura brasileira suas feições peculiares, às vezes paradoxais. Mas, não confrontou o Sistema ou renegou a revolução (para ele, sem aspas, claro), e tampouco colocou em pauta demandas democráticas que fossem além do liberalismo clássico. O Estado de São Paulo ajudou a legitimar o regime político construído a partir do golpe de 1964. Mais do que isso, concorreu para a sua construção ao batalhar para que a ditadura se mantivesse nos limites de uma união tensa entre liberalismo e autoritarismo.

\section{Referências}

ABRAMO, Cláudio. A regra do jogo. São Paulo: Companhia das Letras, 1988.

ABREU, Alzira Alves de. 1964: a imprensa ajudou a derrubar o governo Goulart. In: FERREIRA, Marieta de Moraes (Org.). João Goulart. Entre memória e a história. Rio de Janeiro: Editora FGV, 2006. Vol. 1. p. 107-128.

AQUINO, Maria Aparecida. Censura, imprensa, Estado autoritário (1968-1978): o exercício cotidiano da dominação e da resistência: o Estado de São Paulo e Movimento. Bauru: Edusc, 1999.

CAPELATO, Maria Helena; PRADO, Maria Lígia. O bravo matutino: imprensa e ideologia no jornal $O$ Estado de S. Paulo. São Paulo: Alfa-Omega, 1980.

CORDEIRO, Janaina Martins. A ditadura em tempos de milagre: comemorações, orgulho e consentimento. Rio de Janeiro: Editora FGV, 2015.

GASPARI, Elio. A ditadura derrotada. São Paulo: Companhia das Letras, 2003.

MOTTA, Rodrigo Patto Sá. Os expurgos de 1964 e o discurso anticorrupção na caricatura da grande imprensa. Tempo e Argumento, v. 8, p. 9-39, 2016. https://doi.org/10.5965/2175180308182016009

. A Ditadura nas representações verbais e visuais da grande imprensa (1964-1969). Topoi, v. 14, n. 26, p. 62-85, jan./jul. 2013. https://doi.org/10.1590/2237-101X014026005

SMITH, Anne-Marie. Um acordo forçado. O consentimento da imprensa à censura no Brasil. Rio de Janeiro: FGV, 2000.

Recebido: 14 de setembro de 2016 Aprovado: 20 de dezembro de 2016

\footnotetext{
Autor/Author:

RodRigo PATTO SÁ MOTTA rodrigopsamotta@gmail.com

- Professor do Departamento de História da Universidade Federal de Minas Gerais (UFMG) e pesquisador do CNPq. Autor dos seguintes livros: Em guarda contra o perigo vermelho: o anticomunismo no Brasil (1917-1964). São Paulo: Perspectiva/Fapesp, 2002; Jango e o golpe de 1964 na caricatura. Rio de Janeiro: Zahar, 2006; As universidades e o regime militar: Rio de Janeiro: Zahar/Fapemig, 2014.

Professor of the Department of History of the Universidade Federal de Minas Gerais (UFMG) and researcher of the CNPq. Author of the following books: Em guarda contra o perigo vermelho: o anticomunismo no Brasil (1917-1964). São Paulo: Perspectiva/Fapesp, 2002; Jango e o golpe de 1964 na caricatura. Rio de Janeiro: Zahar, 2006; As universidades e o regime militar. Rio de Janeiro: Zahar/ Fapemig, 2014.
} 